Discussion Paper No. 08-136

\title{
Oil and Unemployment in Germany
}

Andreas Löschel and Ulrich Oberndorfer

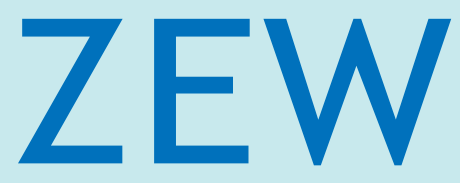

Zentrum für Europäische Wirtschaftsforschung $\mathrm{GmbH}$

Centre for European

Economic Research 
Discussion Paper No. 08-136

\title{
Oil and Unemployment in Germany
}

\author{
Andreas Löschel and Ulrich Oberndorfer
}

Download this ZEW Discussion Paper from our ftp server:

ftp://ftp.zew.de/pub/zew-docs/dp/dp08136.pdf

Die Discussion Papers dienen einer möglichst schnellen Verbreitung von neueren Forschungsarbeiten des ZEW. Die Beiträge liegen in alleiniger Verantwortung der Autoren und stellen nicht notwendigerweise die Meinung des ZEW dar.

Discussion Papers are intended to make results of ZEW research promptly available to other economists in order to encourage discussion and suggestions for revisions. The authors are solely responsible for the contents which do not necessarily represent the opinion of the ZEW. 


\section{Non-Technical Summary}

The recent years have been marked by massive price movements in resource markets. Particularly record high prices for oil have been reached. Although until late 2008, oil prices have decreased from nearly 150 to about 40 dollar within a few weeks, long term scenarios suggest that the era of cheap oil is over. Against this background, this paper addresses possible oil price impacts on unemployment for Germany. Firstly, we survey theoretical and empirical literature on the oil-unemployment relationship and relate them to the German case. Secondly, we illustrate this issue within the framework of a vector autoregression (VAR) approach for Germany. In order to adequately address the issue of oil price effects on unemployment in Germany, we conduct a detailed analysis with two particular features: We, firstly, tackle the question about the nature of oil price effects by making use of three different constructions of oil price movements, namely a simple oil price variable according to Hamilton (1983), an oil price increase according to Mork (1989) in order to address possible asymmetric oil price effects, and the net oil price increase based on Hamilton (1996). This variable compares current oil prices with the maximum value observed during the preceding year and should therefore be a good indicator for an actual oil shock that is not representing immediate oil price corrections to earlier declines. Secondly, against the claim of a changing relationship between oil prices and the macroeconomy since the 1980s, we base our analysis both on a sample period 1973 to 2008 and on a sample period for unified Germany (1990 to 2008). Using monthly data, we show that the oil price - in all three specifications - increase unemployment on the German labor market. For a restricted sample period for postunification Germany, we oppose claims that the oil to macroeconomy relationship has weakened since the 1980s. These results show that, although the German economy has become much more energy-efficient in recent years, its macroeconomy and particularly labor market situation is still very much dependent on the situation in the oil market. This situation, however, seems to be better indicated by (net) oil price increases than by a linear oil price variable. This may be due to the costly resource reallocation in situations of actual oil price shocks (Jones et al., 2004). The result suggests that indeed, as Hamilton (1996) argues, it is rather general concerns about the price and availability of energy instead of fully rational reasoning that result in negative consequences of an oil price increase.

\section{Das Wichtigste in Kürze}

Dieses Papier untersucht die Auswirkungen von Ölpreisen auf die Arbeitslosigkeit in Deutschland. Die letzten Jahre waren geprägt durch starke Preisschwankungen auf den Rohstoffmärkten. Die Preise für Rohöl haben Rekordhöhen erreicht. Obwohl bis Ende 2008 die Preise für Öl wieder stark gefallen sind, wird in allen längerfristigen Energieszenarien davon ausgegangen, dass die Zeit des billigen Öls vorbei ist. Welche Auswirkungen haben Ölpreise auf die Beschäftigung in Deutschland. Um diese Frage zu beantworten, wird zuerst ein Überblick über die theoretische und empirische Literatur zum Verhältnis von Ölpreisen und Arbeitslosigkeit gegeben. Danach wird dieser Zusammenhang im Rahmen eines VektorAutoregressionsmodells (VAR) für Deutschland untersucht. Dabei wird insbesondere auf die Natur des Ölpreisschocks eingegangen. Neben einer linearen Beziehung wie von Hamilton (1983) unterstellt, werden zwei nichtlineare Varianten betrachtet: eine asymmetrischen Spezifikation nach Mork (1989) und der Netto-Ölpreisanstieg nach Hamilton (1996), der den geltenden Ölpreis ins Verhältnis zum Maximum der vier vorhergehenden Quartale setzt. Daneben wird analysiert, ob sich das Verhältnis zwischen Ölpreis und Beschäftigung seit den 1980er Jahren verändert hat. Der Ölpreis erhöht in allen drei Spezifikationen die Arbeitslosigkeit in Deutschland. Das Verhältnis von Ölpreisen zu Beschäftigung hat sich trotz erheblicher Energieeffizienzverbesserungen - nach der Wiedervereinigung nicht abgeschwächt. 


\title{
Oil and Unemployment in Germany
}

\author{
Andreas Löschel ${ }^{\mathrm{a}}$ \\ Ulrich Oberndorfer ${ }^{b}$
}

This Version: January 2009

\begin{abstract}
In this paper, we analyze oil price impacts on unemployment for Germany. Firstly, we survey theoretical and empirical literature on the oil-unemployment relationship and relate them to the German case. Secondly, we illustrate this issue within the framework of a vector autoregression (VAR) approach for Germany. For this purpose, we use three different specifications in order to adequately address the uncertainty related to the construction of an adequate oil variable. Using monthly data from 1973 to 2008, we show that oil price increases induce a rise in unemployment in the German labor market. Moreover, for a restricted sample period for post-unification Germany, we oppose claims that the oil to macroeconomy relationship has weakened since the 1980s. However, our results suggest that it has become more important to construct adequate measures of oil price variables.
\end{abstract}

Keywords: oil price; unemployment; Germany

JEL classification: Q43; E24

Acknowledgement: The authors thank three anonymous referees and particularly the editor Peter Winker for many helpful comments and suggestions. This article represents the personal opinion of the authors and does not reflect the official position of the German Federal Ministry of Economics and Technology.

\footnotetext{
${ }^{\mathrm{a}}$ Centre for European Economic Research (ZEW), P.O. Box 103443, 68034 Mannheim, Germany, loeschel@zew.de

${ }^{\mathrm{b}}$ Federal Ministry of Economics and Technology, Scharnhorststr. 34-37, 10115 Berlin, Germany, ulrich.oberndorfer@bund.bmwi.de
} 
"...for those who have yet to be convinced, I hereby renew the forecast - sometime again within the next ten years, turmoil in the Middle East will produce another major disruption to world petroleum supplies. The crisis will produce a recession".

Hamilton (1996)

\section{Introduction}

The recent years have been marked by massive price movements in resource markets. Particularly record high prices for oil have been reached. About twelve years after James Hamilton's (1996) prophecy of an oil shock-induced recession, indeed many observers express their fear of a new oil crisis, slowing down economic growth and causing important losses in employment. For example, in a recent speech Nobuo Tanaka, Executive Director of the International Energy Agency (IEA), argues that current oil prices were too high and would constitute a threat to economic growth (Tanaka, 2008). Although until late 2008, oil prices have decreased from nearly 150 to about 40 dollar within a few weeks, long term scenarios such as the World Energy Outlook 2008 suggest that the era of cheap oil is over (IEA, 2008).

For the German economy, the fear of an economic slowdown and a subsequent rise in unemployment is particularly strong. As, at least between the 1970s and the middle of the first decade of this century, the German unemployment rate has been more or less steadyly rising, even during recent economic boom phases unemployment has been a severe problem for the German economy. Reasons for this development as well as remedies to the German unemployment problem have been analyzed by numerous authors. Official statistics as well as empirical studies suggest that particularly low-skilled persons are very likely to be hit by particularly long-term - unemployment. Against this background, training programs for lowskilled unemployed persons seem to be promising means to alleviate Germany's unemployment problem indeed (e.g. Franz, 1983, or Steiner, 2001).

This paper also addresses unemployment in Germany, but focuses on a related question not covered to date by the scientific community. Based on time series data for Germany, we tackle the question whether oil shocks may worsen the German labor market situation. Such effect is not only of interest in light of recent oil price increases; indeed, a large majority of energy market experts is convinced that oil prices will continue rising also within the next years (ZEW, 2008). For many countries and world regions, resource - and particularly oil price shocks have been shown to be economically detrimental. E.g. Hamilton (1983) for the U.S. and Papapetrou (2001) for Greece shows that employment and economic activity in general is negatively affected by oil price shocks. As far as empirical evidence for the role of the oil price for the German economy is concerned, the calculations by the German Council of Economic Experts (2006) suggest that industrial production is negatively affected by oil price shocks. In contrast, Schmidt and Zimmermann $(2005,2007)$ find that the macroeconomic impact of oil price shocks is limited. Schmidt and Zimmermann (2007) particularly argue that effects of recent oil price hikes may be offset by higher demand from the world market, a fact that is particularly relevant for the German economy that nowadays is much more open than in the 1970s. Another important factor driving the impact of oil shocks down is, according to Schmidt and Zimmermann (2007), the diminishing energy intensity of German production. However, their analysis is temporally restricted until 2002. Moreover, the analyses of the German Council of Economic Experts (2006) and of Schmidt and Zimmermann (2005, 2007) do not provide evidence on the question whether and how (un)employment in Germany is affected by oil price shocks. Given the unemployment problems Germany has been facing for 
several decades, and the importance of this relationship particularly in times of pronounced oil price rises, this paper aims to fill this gap.

In order to adequately address the issue of oil price effects on unemployment in Germany, we conduct a detailed analysis with two particular features: We, firstly, tackle the question about the nature of oil price effects by making use of three different constructions of oil price movements, namely a simple oil price variable according to Hamilton (1983), an oil price increase according to Mork (1989) in order to address possible asymmetric oil price effects, and the net oil price increase based on Hamilton (1996). This variable compares current oil prices with the maximum value observed during the preceding year and should therefore be a good indicator for an actual oil shock that is not representing immediate oil price corrections to earlier declines. Secondly, against the claim of a changing relationship between oil prices and the macroeconomy since the 1980s (Jones et al., 2004, and for Germany Schmidt and Zimmermann, 2007), we base our analysis both on a sample period 1973 to 2008 and on a sample period for unified Germany (1990 to 2008). The remainder of this paper is structured as follows: Section 2 highlights the background for this study. Section 3 presents the methodological approach, data and variables used as well as the results of the empirical analysis. Section 4 concludes.

\section{Oil and the labour market: An overview}

Although different channels have been proposed to account for the relationship between oil price movements and economic activity, the most common explanation is the supply-side effect. It describes that rising oil prices indicate the reduced availability of a basic input - oil - to production (e.g. Brown and Yücel, 1999). ${ }^{1}$ As a consequence of this scarcity, the growth of output and productivity are slowed down. The decline in productivity growth lessens real wage growth, and employment.

According to Brown and Yücel (2002), such effect works as follows: If wages are nominally sticky downward, the oil price-induced reduction in GDP growth will lead to increased unemployment and a further reduction in GDP growth. This relationship holds unless unexpected inflation increases as much as GDP growth falls. The initial reduction in GDP growth is accompanied by a reduction in labor productivity. Unless real wages fall by as much as the reduction in labor productivity, firms will lay off workers, which will increase unemployment and cause further GDP losses. If wages are nominally sticky downward, according to Brown and Yücel (2002), the only mechanism through which a wage reduction necessary for the stabilization of employment can occur is through unexpected inflation that is at least as great as the reduction in GDP growth.

Subsequently to the seminal paper by Hamilton (1983), a bunch of empirical papers has supported such theory-rooted negative economic effect of the oil price for the period of the 1940s until the 1970s. From more recent empirical literature, it seems, however, that the postWorld War II relationship between oil prices and macroeconomic indicators such as production and employment changed - decreased - sometime in the 1980s. According to Jones et al. (2004), the meaning of this change in the oil price effect is quite important, as it can be interpreted in different ways. It is perceivable that oil prices never played such important role as suggested e.g. by Hamilton (1983). If this would be the case, empirical research just was not able to provide this information due to data problems, particularly due to

\footnotetext{
${ }^{1}$ Other explanations include income transfers from the oil-importing nations to the oil-exporting nations, a real balance effect and monetary policy (Brown and Yücel, 2002).
} 
the short available time series. In contrast, a further argument states that oil prices affected the economy until the 1980s, but stopped to do so since that time.

Related to this, Brown et al. (2003) claim the predominance of oil demand rather than supply shocks in recent years. While the oil price shock in the 1970 was caused by political (supply) reasons, recent oil price rises seem to be rather a result of economic expansion. Recent world oil consumption is particularly boosted by the dramatic gains in oil consumption outside the OECD, with the strongest gains in consumption occurring in the newly industrializing Asian countries such as China or Korea. Against this background e.g. Lin (2008) argues that particularly demand from China has caused the recent oil price hike. The Asian oil consumption boost, however, is accompanied by a rise in overall demand from the Far East, which itself is economically beneficial for Western European countries. Moreover, Rotemberg and Woodford (1996) relate the finding of a change in the oil price effect to their observation that sometime after 1980 OPEC lost its ability to keep the nominal price of oil relatively stable. Thereafter, variations in the demand for oil were reflected quickly in nominal price changes, and several statistical properties of oil prices changed as a result. A further argument why the oil price effect on employment has diminished over the past decades is that energy intensity practically all over the world has been declining. According to Greening et al. (1997), this decline seems to be particularly strong for Germany. This result is largely driven by shifts in the production activity mix since the 1970s. These shifts have worked towards less energy-intensive activities. This could imply that currenlty production and employment in Germany is less related to oil market developments compared to the past.

Barsky and Kilian (2004) provide a summary of the effects of fluctuating oil prices on the US economy since the 1970s. They discuss different theoretical explanations for a causal link from oil prices to recessions, inflation and economic growth. However, they find little empirical evidence for the different channels or transmission mechanisms and concluded that oil price shocks can not be held responsible for the macroeconomic performance in the United States.

Apart from the discussion about channels or transmission mechanisms of oil price shocks on the economy, previous literature has pointed out that, in order to correctly measure the effects of oil price shocks, one has to adequately address the nature of oil price movements themselves. While Hamilton (1983) in his pioneering work established a negative economic effect of oil prices, subsequent research has argued that such linear negative relationship could only have been established against the background of the 1973 oil crisis that is included in Hamilton's (1983) data set. In this respect, Mork (1989) makes use of asymmetric oil price variables. His results suggest that the negative effect of oil price increases on the macroeconomy is not an artefact of Hamilton's (1983) data, particularly persisting in different samples. However, Mork (1989) shows that "an asymmetry in the responses is quite apparent in that the correlation with price decreases is significantly different and perhaps zero" (p. 744). There are different argumentations at hand that may explain such asymmetric effect. Hamilton (1996) notes that historical oil crises have been characterized by widespread concern about the price and availability of energy, potentially causing irreversible investment decisions to be postponed. This would not mean, however, that an oil price decrease would produce an economic boom that mirrors the recession induced by an oil price increase, i.e., the economic effects of the oil price would work asymmetrically.

In response to Hooker (1996), who demonstrated that neither the linear relation between oil prices and the macroeconomy proposed by Hamilton (1983) nor the asymmetric relation based on oil price increases alone advocated by Mork (1989) is consistent with observed 
economic performance during the 1990s, Hamilton (1996) proposes a further definition of an oil price variable. As many increases in oil prices follow immediately comparable or even larger decreases, Hamilton (1996) argues that a simple asymmetric oil price variable may be a bad measure of oil price movements. It would therefore be more appropriate to compare the current price of oil with where it has been over the previous year rather than during the previous period alone. The corresponding oil price movement variable, the net oil price increase, therefore compares the price of oil with the maximum value observed during the preceding year. If the value for the current period exceeds the previous year's maximum, the value of the variable is assigned to the change over the previous year's maximum. If the price of oil in the current period is lower than it had been at any point during the previous year, the series is defined to be zero for the current period. Hamilton (1996) shows that this variable outperforms other oil price measures in Granger causality tests.

\section{Empirical analysis}

\subsection{Methodological approach}

The empirical analysis addresses economic impacts of oil price movements for the German macroeconomy. We apply a vector autoregression (VAR; Sims, 1980) approach using monthly data from Germany. An important choice for this type of analysis relates to the form - levels or first differences - of the variables employed. This relates to the question whether the variables employed contain one (or more) unit root(s): If the respective variables are stationary, i.e. do not contain a unit root, the VAR can be estimated in levels. If one or more variables, however, contain at least one unit root, spurious regression (Granger and Newbold, 1974) can occur, which means that the null hypothesis of no significant relationship between variables employed would be rejected in by far more cases than suggested by the respective significance levels from a t-Test. Finally, if variables containing unit roots follow a common long term relationship i.e. are cointegrated, an estimation of an error correction model is theoretically beneficial (Engle and Granger, 1987). However, the performance of vector error correction models is contested particularly at short horizons (e.g. Naka and Tufte, 1997). Against this background, some authors from the energy economics community prefer to generally estimating VAR models in levels (for an extensive discussion cp. e.g. Farzanegan and Markwardt, 2008). We follow other authors from the related literature such as Ferderer (1996) and estimate the VAR model using stationary transformations of those series that exhibit unit roots.

All in all, we estimate three different VAR specifications: One specification using a simple linear - oil price variable according to Hamilton (1983), one using an asymmetric oil price variable according to Mork (1989), and one model consistently with Hamilton (1996) using the net oil price increase as oil price movement variable. As it is common in the existing literature, the empirical approach followed in this paper has different steps: We firstly apply unit root tests in order to check whether the VAR model can be estimated in levels or first differences of the variables included. Next, we conduct Granger causality tests. Finally, we estimate VAR models and subsequently apply impulse response functions. The interpretation of this VAR approach is based on impulse response functions that give the response of one variable of the respective VAR system to an innovation in another variable of the system.

\subsection{Data and Variables}

The empirical analysis conducted addresses economic impacts of oil price movements for the German macroeconomy. We apply a VAR approach using monthly data from Germany for a 
long time series from October 1973 to January 2008. Due to this long sample period, periods of oil price hikes such as in the early 1980s and, more recently, in 2006 to 2008 as well as periods of relatively stable oil prices such as in the 1990s are included. On the one hand, this seems to be very important, as a restrictive sample period selection that particularly considers only periods of oil price hikes or, respectively, of stable oil prices has been shown to drive the results of analyses of oil price effects (e.g. Mork, 1989). On the other hand, authors such as Jones et al. (2004) and, particularly for Germany, Schmidt and Zimmermann (2007) have argued that since the 1980s, the oil price-macroeconomy relationship has changed in a way that since that time, the oil price has not been that decisive for the (German) economy any more. Against this background, we additionally base or analysis on a shorter sample, namely for post-unification Germany from October 1990 to January 2008.

Our VAR approach is inspired by the recent literature on the economic impacts of the oil price such as Hooker (1996), Hamilton (1996), or Papapetrou (2001). We consider unemployment, the oil price, industrial production, interest rate and inflation rate in our empirical approach. Data on industrial production stems from the OECD, the oil price is taken from the U.S. Energy Information Administration's (EIA) database, and data on unemployment, the interest rate and the inflation rate stem from the time series database of Deutsche Bundesbank (German Central Bank; based on data from the German Federal Statistical Office). Unemployment and industrial production data reflects the Federal Republic of Germany (FRG) in a way that starting from the German unification in October 1990, data from reunified Germany (including both the former FRG - West Germany - and the former German Democratic Republic - East Germany) is used. In order to control for the reunification effect, in the analysis for the whole sample period a reunification dummy taking the value of one starting from October 1990 (zero otherwise) is used. In order to control for seasonality, we use centered (orthogonalized) seasonal dummy variables at a monthly basis instead of seasonally adjusted variables. This is due to the fact that using seasonally adjusted variables may affect the model specification and lead to spurious regression problems (Meyer and Winker, 2005). Apart from seasonality, outliers may affect the results of such empirical analysis. Particularly, Flaig (2005) argues that the German production index shows a nonnegligible outlier during 1984. Moreover, Barnsky and Kilian (2004) relate high values for oil variables, e.g., in the 1970s, to war-induced cuts in oil supply. Additional estimation results based on models with dummy variables in order to cope with such possible problems are available on request from the authors; however, the inclusion of such dummy variables does not strongly affect the results presented in this paper.

For industrial production, we use a (total industry) production index calculated to the base year 2000 (value 100). The unemployment variable gives the number of unemployed persons in Germany (in 1000). The interest rate employed reflects money market rates in Frankfurt, the most important German banking centre. Rates for overnight money (monthly averages) in real terms are given. The real interest rate is calculated at an ex post basis making use of the annual inflation rate based on the consumer price index from the time series database of Deutsche Bundesbank (German Central Bank; based on data from the German Federal Statistical Office). This annual inflation rate is also included in the estimated model. As far as the oil price is concerned, we opted for the Import Costs Data published by the U.S. EIA. It is deflated using the German consumer price index (see above) and therefore a real oil price series, and converted to domestic currency using exchange rates from the time series database of Deutsche Bundesbank (German Central Bank; based on data from the German Federal Statistical Office). We opted for the U.S. EIA data as it is, in comparison to monthly data from comparable databases, a relatively long time series. We use the German consumer price 
index in order to calculate real series as the analysis has a focus on the German economy. All variables used in the empirical analysis are in logs.

As lined out in the preceding chapter, there is no consensus which kind of oil series to be used in an analysis of oil price impact on the macroeconomy. In order to address this point which is important from a robustness point-of-view, we apply the three most common definitions of oil price series established in the literature. Besides using a simple (logged) oil series (oil; similar to Hamilton, 1983; see Figure 1 for a plot of dloil, the first differences of this series), we use an asymmetric oil price increase series based on Mork (1989, see Figure 2), defined as

dloilpos $_{t}=\max \left(0, \log \left(\right.\right.$ oil $\left._{t}\right)-\log \left(\right.$ oil $\left.\left._{t-1}\right)\right)$.

with oil $l_{t}$ representing oil import costs at time $t$. Finally, we employ the so-called net oil price increase (nopi $i_{t}$ ) according to Hamilton (1996, see Figure 3), defined as

nopi $_{t}=\max \left(0, \log \left(\right.\right.$ oil $\left._{t}\right)-\max \left(\log \left(\right.\right.$ oil $\left._{t-1}\right), \log \left(\right.$ oil $\left._{t-2}\right), \ldots, \log \left(\right.$ oil $\left.\left.\left._{t-12}\right)\right)\right)$.

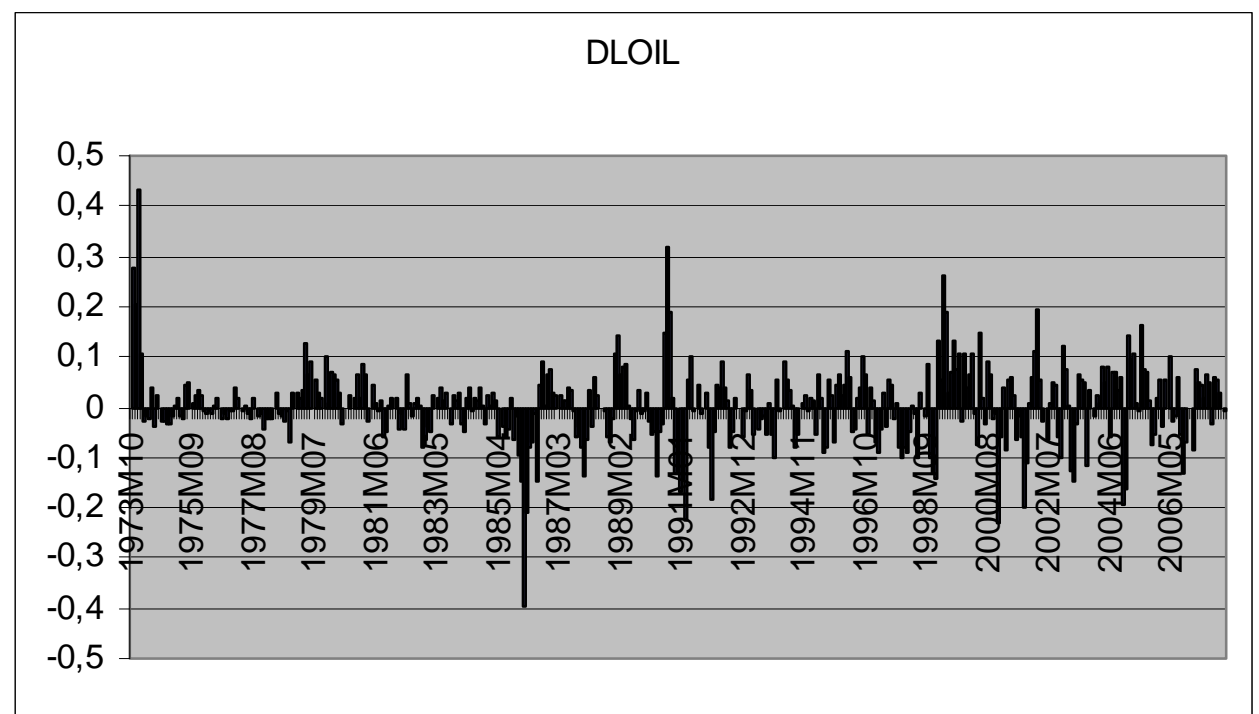

Figure 1 Real oil index change (dloil; based on Hamilton, 1983)

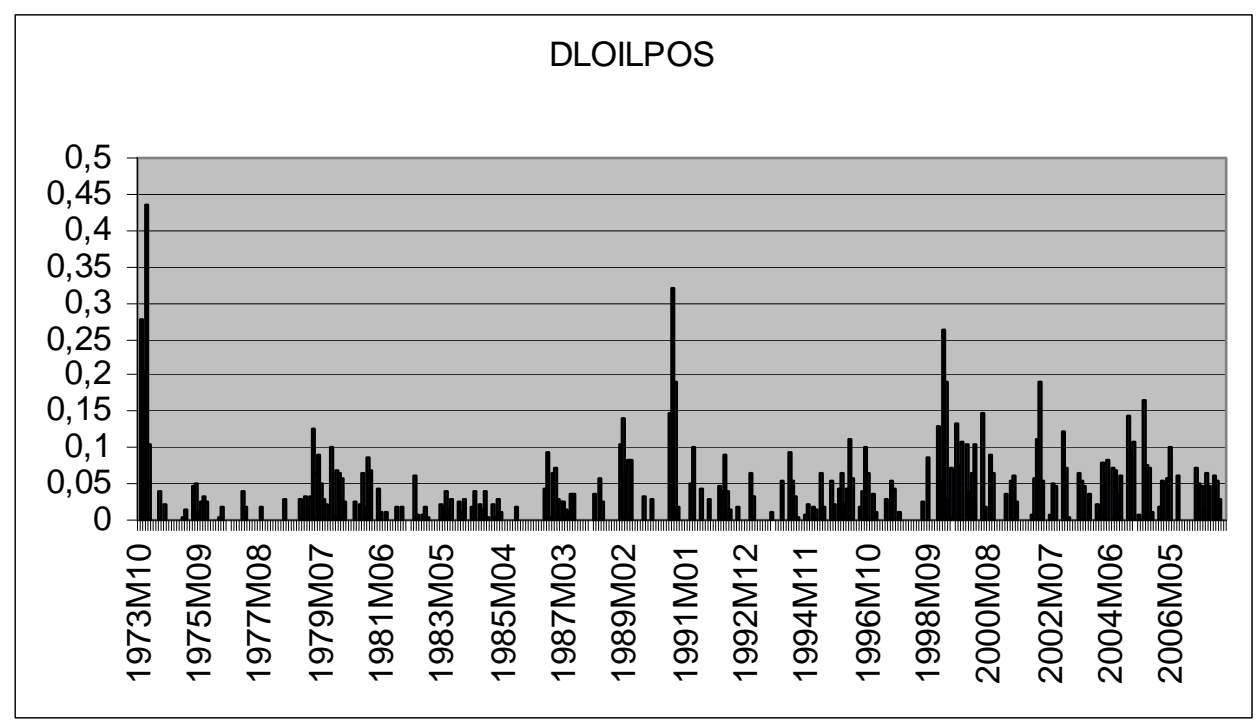

Figure 2 Oil index increase (dloilpos; based on Mork, 1989) 


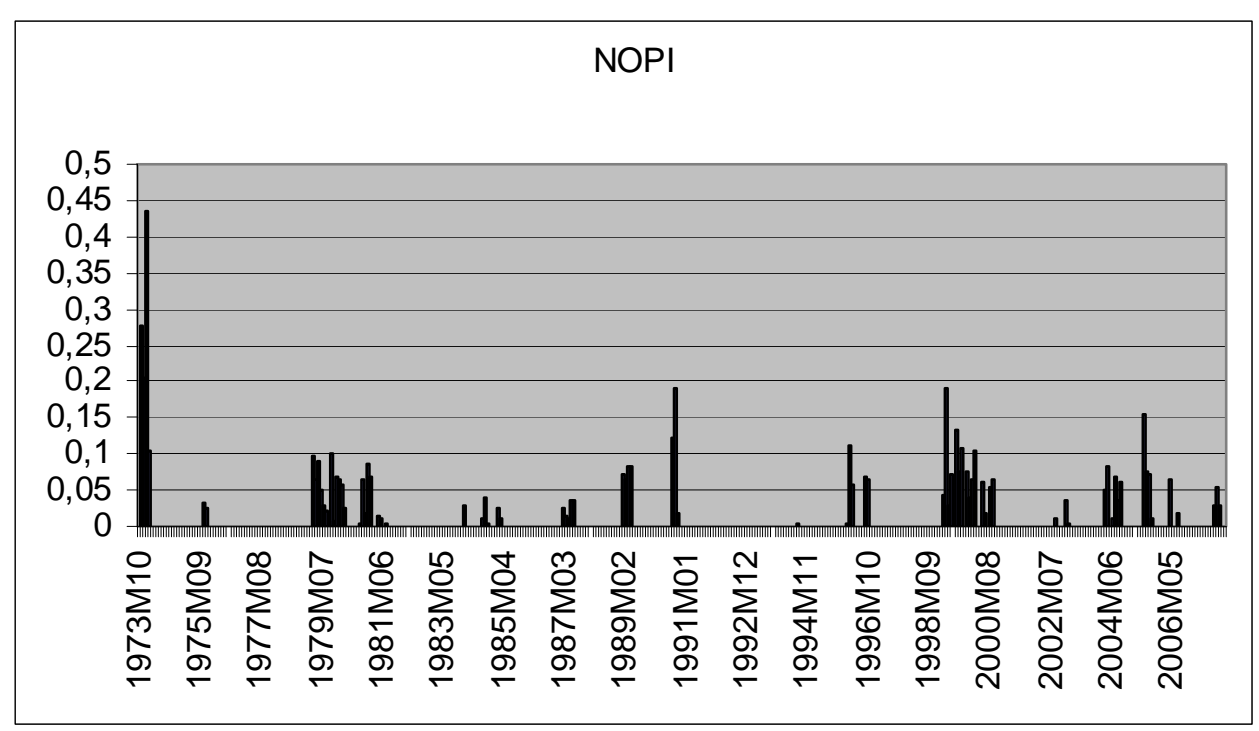

Figure 3 Real net oil index increase (nopi; based on Hamilton, 1996)

The application of the Augmented Dickey-Fuller (ADF), Phillips-Perron (PP), and the Kwiatkowski-Phillips-Schmidt-Shin (KPSS) unit root tests (Table 2; for the 10/1990 to 01/2008 sample, see Table 3) suggest that the oil price movement variables both based on Mork (1989) and Hamilton (1996) - that are a particular form of differenced oil prices - are $\mathrm{I}(0)$ according to all testing procedures for both sample periods. All other variables employed - the oil price, unemployment, interest rate, production and inflation rate variable - seem to be I(1). For the oil price, all unit root tests applied indicate the existence of one unit root for both sample periods (only the ADF provides weak evidence for the oil price being $\mathrm{I}(0)$ for the $10 / 1990$ to $01 / 2008$ sample). For unemployment, evidence is compelling with respect to the existence of one unit root for the full sample. For the 10/1990 to 01/2008 sample, at least the KPSS Test indicates that the variable is I(1). The interest and the inflation rate as well are I(1) according to all testing procedures. For industrial production, results are partly conflicting, but I(1) seems to be most realistic for this variable as well.

\subsection{Results}

Against the background of the unit root tests mentioned in the previous subsection, we firstly conduct Granger causality tests based on the three different constructions of the oil price variable. Secondly, we estimate VAR models and subsequently apply impulse response functions. Impulse response functions give the response of one variable of the respective VAR system to an innovation of another variable of the system. We compute impulse responses according to generalized impulse response functions. Unlike the orthogonalized impulse response functions obtained using the Cholesky factorization, this approach allows to compute impulse responses that are invariant to the ordering of variables in the VAR (Koop et al., 1996). These generalized impulse responses are unique and fully take into account the historical patterns if correlation is observed amongst different shocks. The fact that generalized impulse responses are invariant to any reordering of variables is helpful as there is no clear guidance concerning the exact parametrisation of our VAR model. However, their disadvantage is that generalized impulse responses cannot be interpreted as reflecting the effect of an orthogonal shock. Our results are very robust against the choice of impulse response calculation; results from other approaches are available on request from the authors. According to existing literature using monthly data such as Papapetrou (2001), we initially estimate three versions - an 18, 12 and an 8-lag version - of each VAR model. The 
appropriate lag lengths of the preferred models are determined according to the Schwarz Information Criterion (SIC). According to this criterion, 12-lag models are most suited irrespective of the oil variable used and are therefore applied for Granger causality testing as well as for the VAR models themselves (results using different lag lengths do barely deviate from those presented in this paper, and are available on request from the authors). Confidence bands of inpulse responses are determined making use of Monte Carlo simulations (100 repetitions).

As Granger causality / block exogeneity tests using I(1) variables may give spurious results (He and Maekawa, 2001), we conduct those tests using first differences for all I(1) variables. The respective tests for all three different constructions of the oil price variables are given in Table 1.

Table 1 Block exogeneity test

\begin{tabular}{|l|l|l|l|l|}
\hline Dep. Var.: dl Unemployment & Full sample period (10/1973-01/2008) & \multicolumn{2}{|l|}{ Sample period 10/1990-01/2008 } \\
\hline $\begin{array}{l}\text { Specification (oil variable } \\
\text { used) }\end{array}$ & Chi-Sq. & Prob. & Chi-Sq. & Prob. \\
\hline dloil & 98.84 & 0.00 & 103.77 & 0.00 \\
\hline dloilpos & 117.46 & 0.00 & 130.72 & 0.00 \\
\hline nopi & 101.03 & 0.00 & 100.17 & 0.00 \\
\hline
\end{tabular}

Note: $\mathrm{dl}$ indicates that the variable is employed in differenced and logarithmic form. Block exogeneity test on joint significance of all variables used based on VAR estimation with 12 lags. No. obs.: 393 (full sample period); 208 (sample period 10/1990-01/2008).

According to the results of those tests, all models show high statistical significance. Moreover, all oil price variables used Granger cause unemployment in Germany for both sample periods. The results moreover indicate that industrial production, in contrast to the interest and inflation rate, is a main driver of unemployment in Germany. Granger causality / block exogeneity tests that are not reported in Table 1 of this paper are available on request from the authors. The main result regarding the oil price suggest that none of the macroeconomic variables Granger causes any of the oil variables, while the oil variables particularly Granger cause both the interest and the inflation rate variable.

The results from Granger causality tests are underpinned by the VAR analysis itself. Here, we use, where necessary, stationary transformations of the respective variables as for the Granger causality tests (see Data and Variables as well as the unit root tests in Table 2 and Table 3 in the appendix). Impulse response functions (IRFs) according to generalized IRF approach give the response of one variable of the respective VAR system to a generalized one standard deviation innovation of another variable of the system. IRFs for all variables are reported in rates. Multiplying these values by 100 gives percentage values. Bands around the impulse responses give the 95\% confidence interval. This analysis focuses on the effects of an innovation from the oil variables, and particularly on the responses of the unemployment variable. Impulse response functions for other variables are not shown in this paper, but are available on request from the authors.

For the full sample period, the impulse response functions based on all three VAR specifications (according to the three different definitions of the oil variable) have roughly the same shape. However, the impact on unemployment for the simple oil variable according to Hamilton (1983; Figure 1) is relatively weak and only marginally statistically significant based on the 95\% confidence interval. For the oil price increase according to Mork (1989; Figure 5) and for the net oil price increase as introduced by Hamilton (1996), the unemployment response is stronger and statistically significant (see Figure 6). For all three specifications, the oil effect has its climax about three months subsequently to the oil shock. 
This is relatively early compared to studies on oil price effects in the U.S., but, e.g., comparable to the effects found for Greece (Papapetrou, 2001).

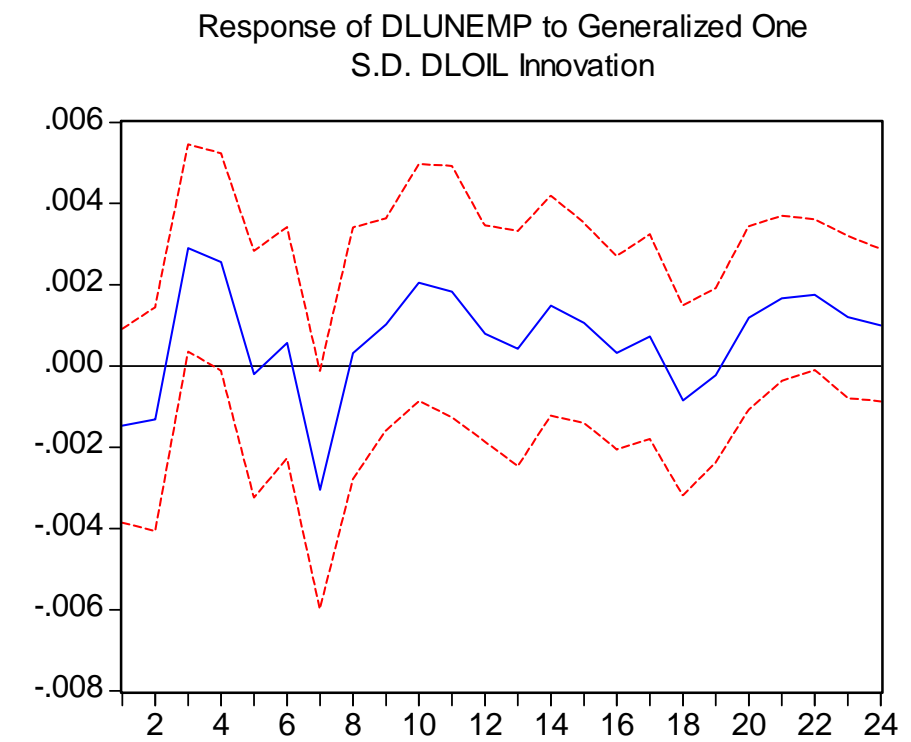

Figure 4 Unemployment response to oil price innovation (full sample period)

Response of DLUNEMP to Generalized One

S.D. DLOILPOS Innovation

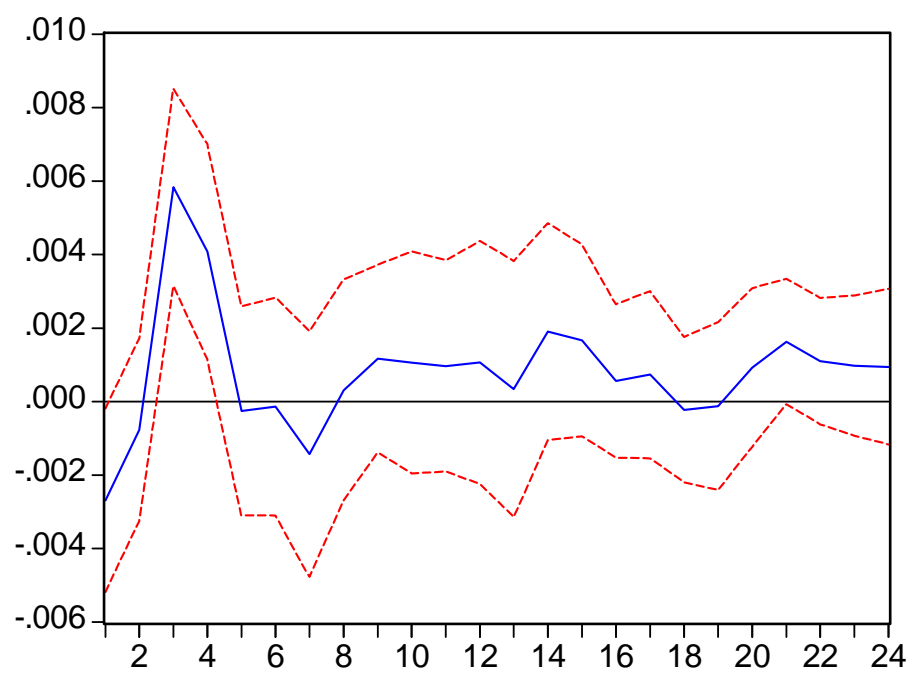

Figure 5 Unemployment response to oil price increase innovation (full sample period) 


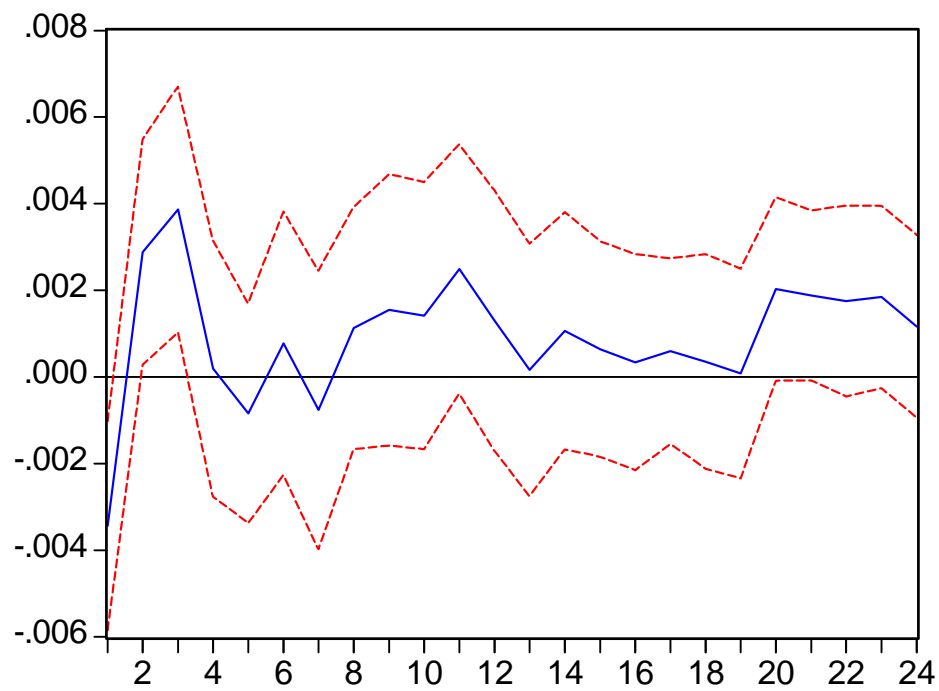

Figure 6 Unemployment response to net oil price increase innovation (full sample period)

Against the claims of a decreased importance of the oil price for the German (macro)economy in recent years, impulse response functions for our VAR models indicate that the effect of oil price movement on unemployment in Germany has not vanished by far. For the postunification sample period (10/1990-01/2008), the impulse responses based on all three VAR specifications are comparable to those calculated for the full sample period. Here as well, the impact on unemployment for the simple oil variable according to Hamilton (1983; Figure 7) is weaker - from both an economic and a statistical perspective - than for the oil price increase according to Mork (1989; Figure 8) and for the net oil price increase as introduced by Hamilton (1996; see Figure 9). Interestingly, the oil price increase according to Mork (1989) gives the most significant reesults here. The shape of all three impulse responses (referring to the three different VAR specifications) is relatively similar to those calculated from the full sample period VARs, with two oil effect hikes about three months as well as eleven months subsequently to the oil shock.

Response of DLUNEMP to Generalized One S.D. DLOIL Innovation

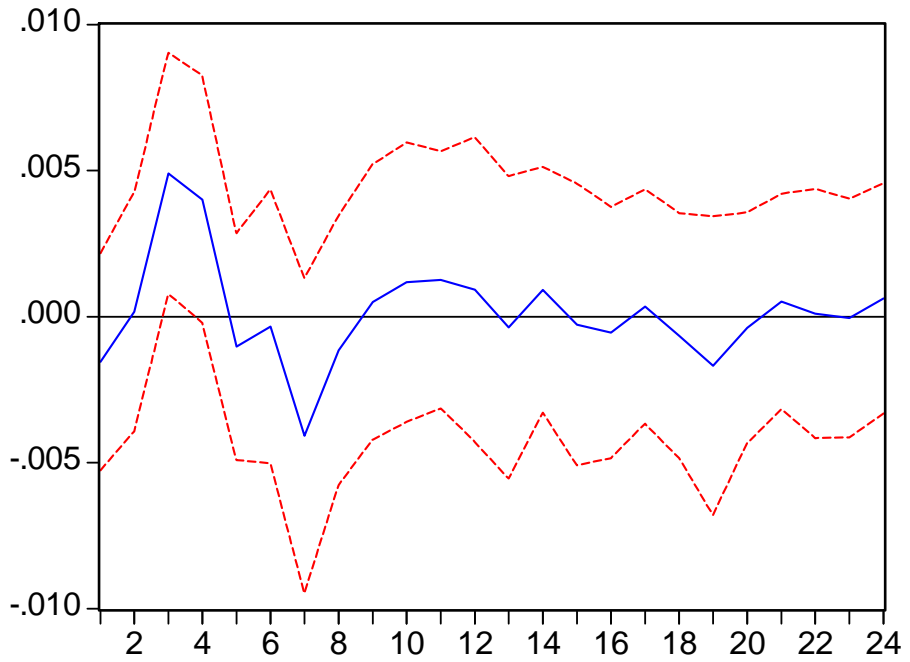

Figure 7 Unemployment response to oil price innovation (10/1990-01/2008) 


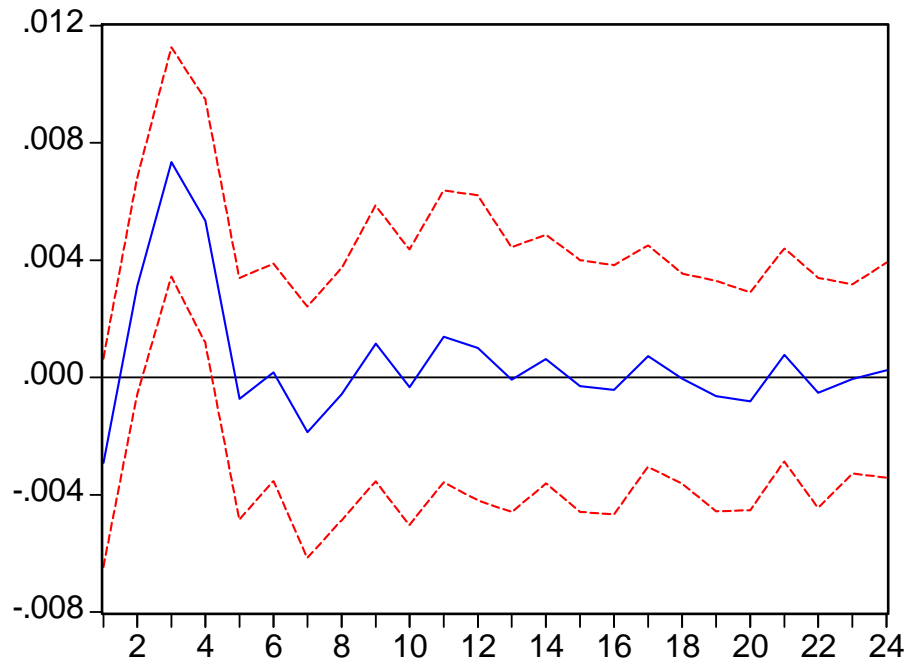

Figure 8 Unemployment response to oil price increase innovation (10/1990-01/2008)

Response of DLUNEMP to Generalized One

S.D. NOPI Innovation

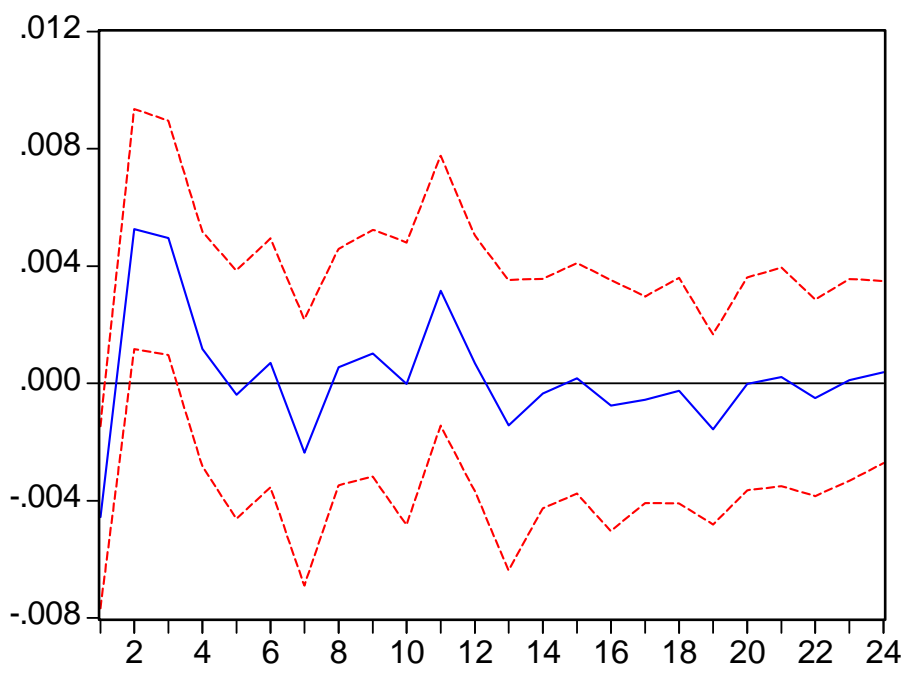

Figure 9 Unemployment response to net oil price increase innovation (10/1990-01/2008)

The results from these impulse responses, together with Granger causality tests, indicate that there is indeed a negative oil price effect on the German labor market. Particularly, this effect seems to be rather constant over the last decades: There is no indication that in recent years, oil price movements affect unemployment in Germany in a different way than they have done since the 1970s. 


\section{Conclusions}

The recent years have been marked by massive price movements in resource markets. Particularly record high prices for oil have been reached. Against this background, this paper addresses possible oil price impacts on unemployment for Germany. Firstly, we survey theoretical and empirical literature on the oil-unemployment relationship and relate them to the German case. Secondly, we illustrate this issue within the framework of a vector autoregression (VAR) approach for Germany. For this purpose, we use three different specifications in order to address the uncertainty related to the construction of an adequate oil variable. Using monthly data from 1973 to 2008, we show that the oil price - in all three specifications - increase unemployment on the German labor market. For a restricted sample period for post-unification Germany, we oppose claims that the oil to macroeconomy relationship has weakened since the 1980s. Our results suggest that a simple oil price variable, but particularly oil price increases according to Mork (1989) or according to Hamilton's (1996) net oil price increase significantly affect unemployment in post-unification Germany. This result is confirmed by impulse response functions that show a significant unemployment response about three months subsequently to a respective oil price shock. The IRFs also suggest that the magnitude of oil price effects on unemployment in Germany has not diminished in the last decades.

These results show that, although the German economy has become much more energyefficient in recent years, its macroeconomy and particularly labor market situation is still very much dependent on the situation in the oil market. Developments in the oil market are crucial from an economic point of view. They, however, seem to be better indicated by (net) oil price increases than by a linear oil price variable. This may be due to the costly resource reallocation in situations of actual oil price shocks (Jones et al., 2004). The result suggests that indeed, as Hamilton (1996) argues, it is rather general concerns about the price and availability of energy instead of fully rational reasoning that result in negative consequences of an oil price increase. This may indicate that the German energy efficiency improvements realized in the past 20 years did not have drastic (alleviating) impacts on the oilmacroeconomy relationship.

Given these results, it seems possible that the importance of energy prices for the macroeconomy has simply been underestimated in recent years. Besides the fact that developments in energy markets have made it more difficult to compute adequate oil price price movement variables, also the relatively uneventful energy market situation with, particularly in the 1980s and 1990s, only modest net oil price increases (see Figure 3) may have contributed to such assessment of the oil-macroeconomy relationship. In the light of long-term scenarios of further increasing oil prices, the results suggest that future developments in the oil market will constitute a burden on the German labor market. Future research may particularly tackle the question about how economic and energy policy can effectively fight this unpleasant oil-to-labor market relationship. Apart from that, further measures of oil price variables such as the transformation proposed by Lee et al. (1995; cp. Hamilton, 2003) could be applied. This paper concentrates on the application of three of the most common measures. Moreover, further variables, e.g., measures of wage dynamics, could be integrated into the empirical approach presented here. Also, an analysis that explicitly tackles the unemployment rate or cyclical unemployment seems promising. 


\section{Appendix}

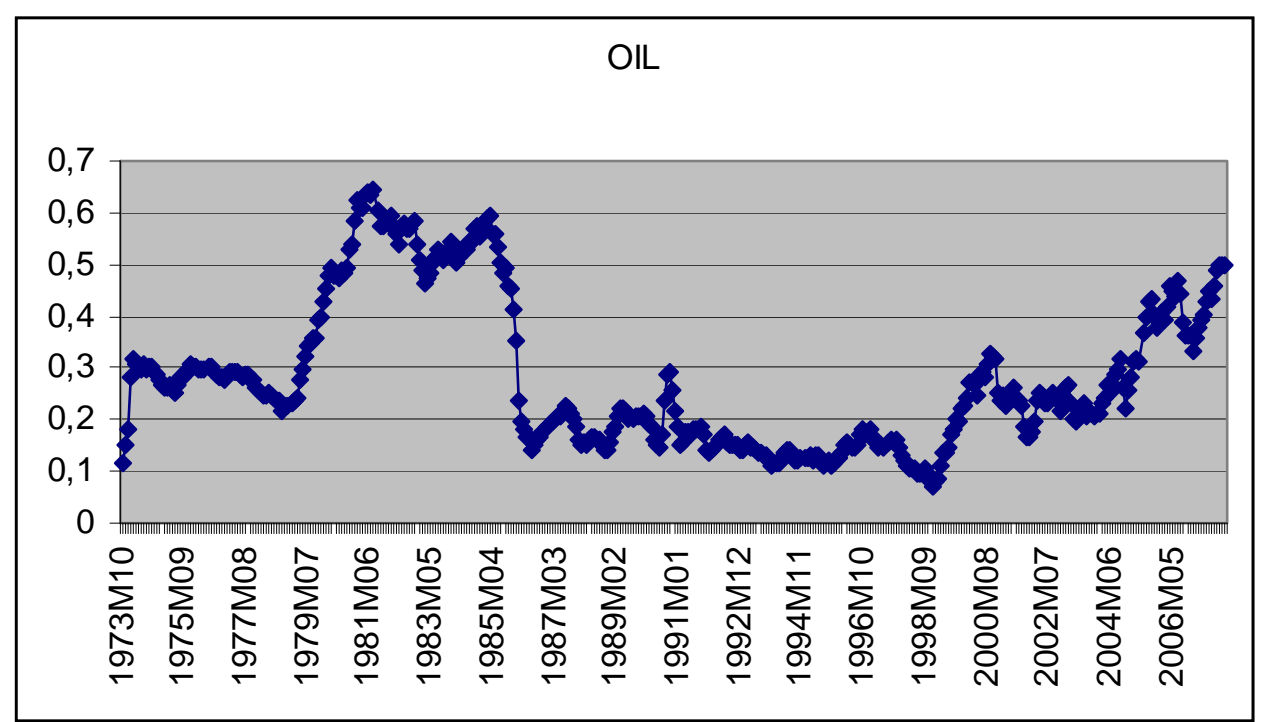

Figure 10 Oli price (oil; deflated; in domestic currency)

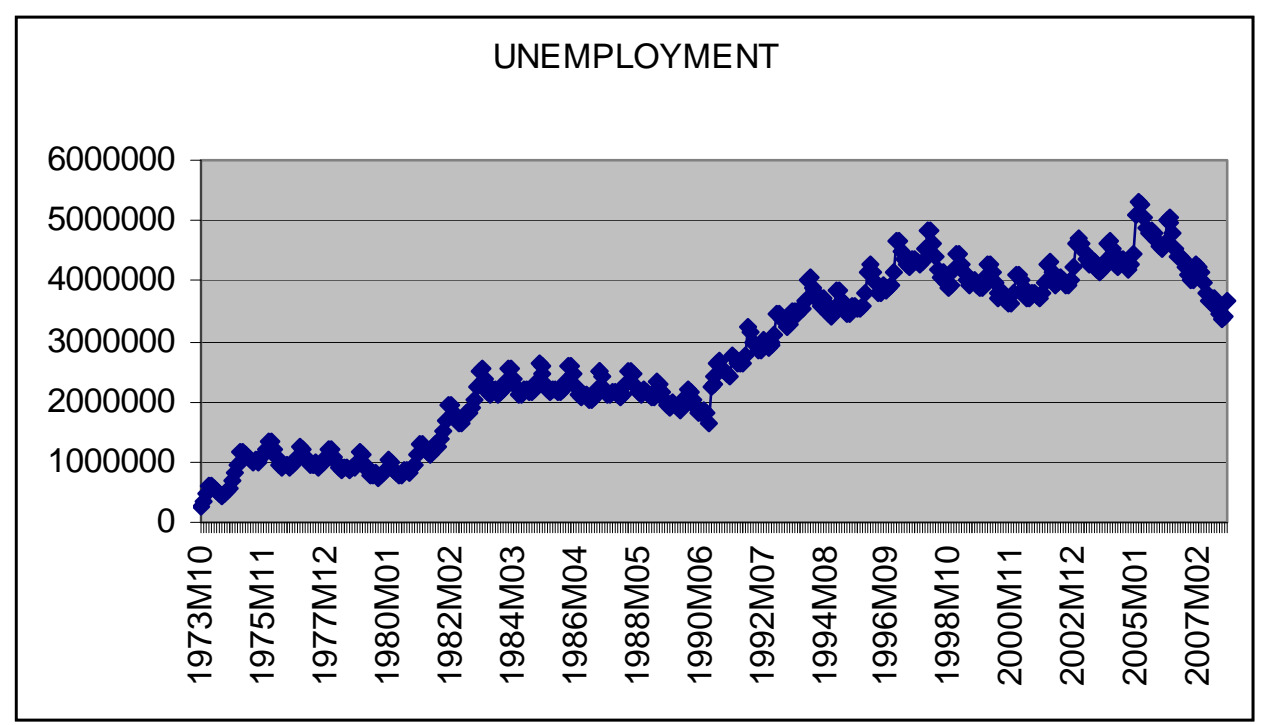

Figure 11 Unemployment in Germany (number of unemployed persons) 


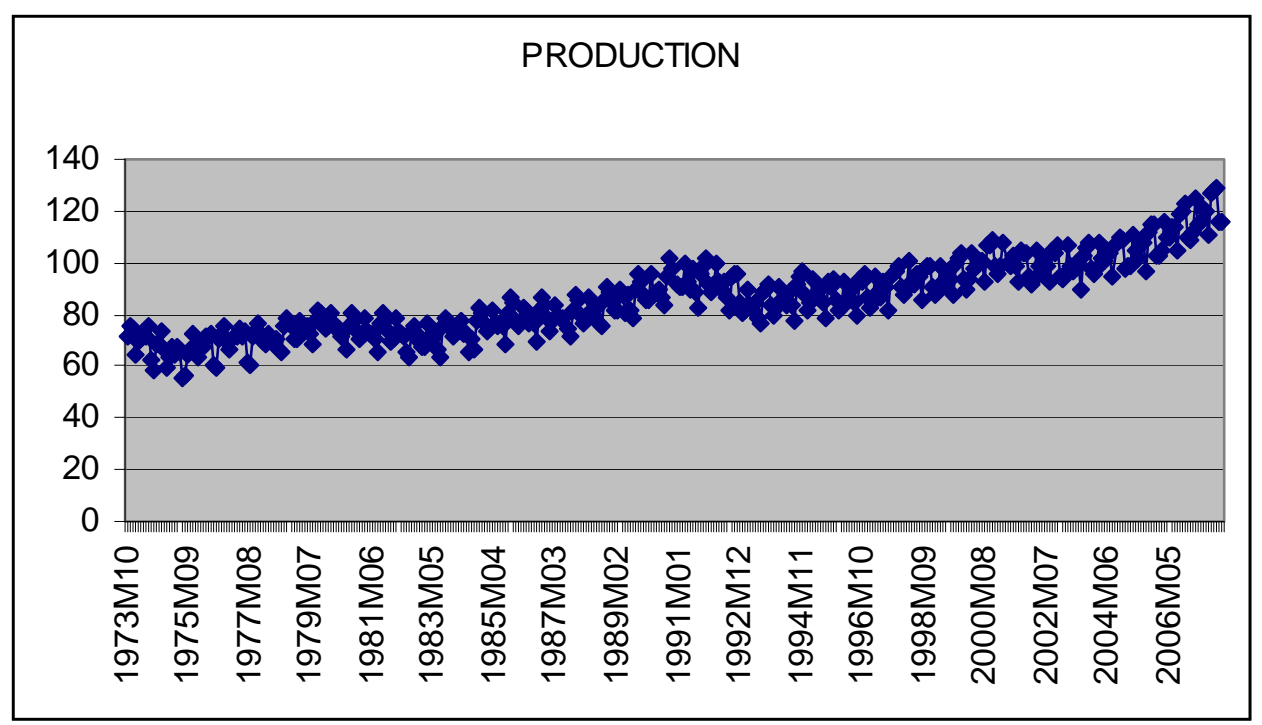

Figure 12 Production of total industry in Germany (index: base year 2000 - value 100)

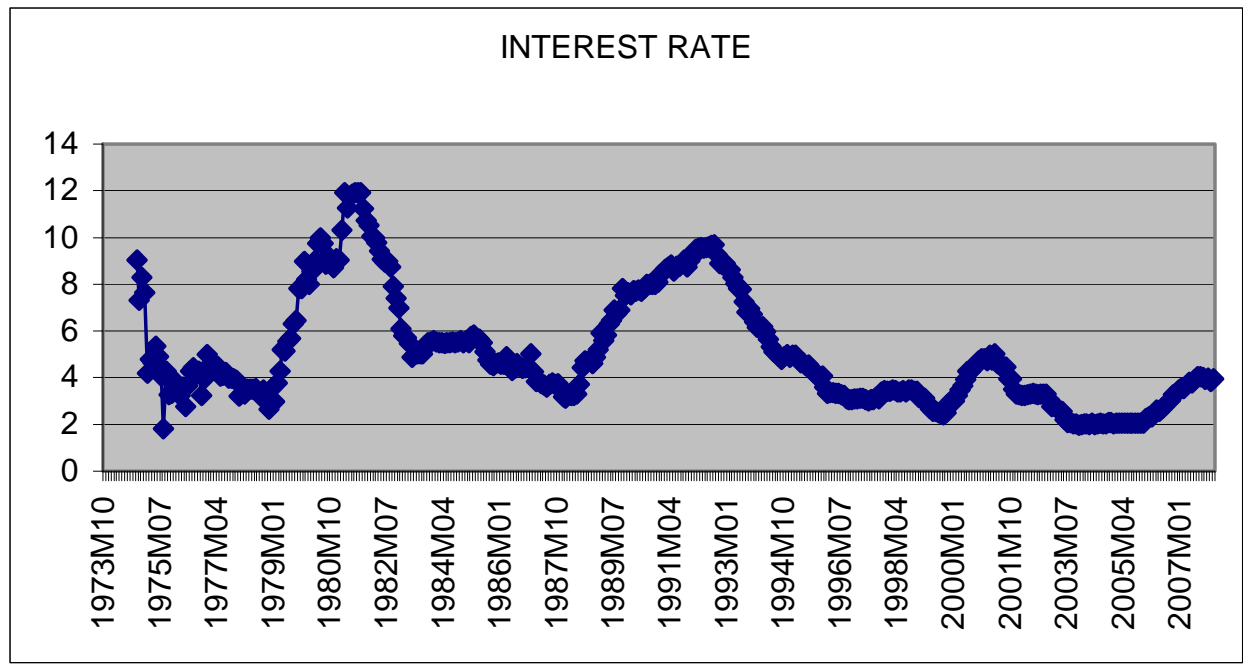

Figure 13 Interest rate (real; based on rates for overnight money in Frankfurt, Germany)

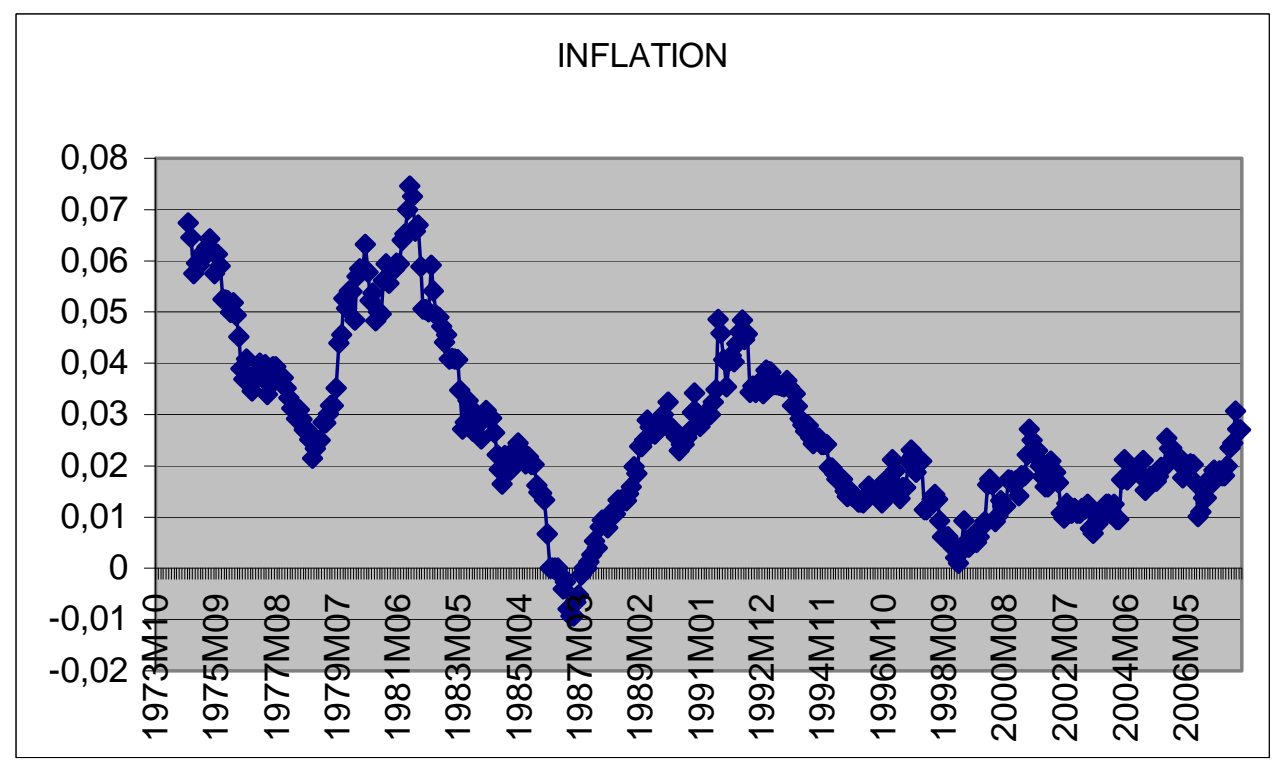

Figure 14 Inflation rate (annual; based on the German consumer price index) 
Table 2 Unit root tests full sample period (10/1973-01/2008)

\begin{tabular}{|l|l|l|l|l|l|l|}
\hline & Levels & \multicolumn{3}{l|}{$\mathbf{1}^{\text {st }}$ Differences } \\
\hline & ADF & PP & KPSS & ADF & PP \\
\hline I Unemployment & -2.70 & $-4.69^{* * *}$ & $0.35^{* * *}$ & $4.46^{* * *}$ & $-11.22^{* * *}$ & 0.06 \\
\hline I Oil price (oil) & -2.30 & -2.23 & $0.32^{* * *}$ & $-12.54^{* * *}$ & $-11.89^{* * *}$ & $0.17 * *$ \\
\hline I Oil price increase (dloilpos) & $-13.05^{* * *}$ & $-12.63^{* * *}$ & 0.08 & - & - & - \\
\hline I Net oil price increase (nopi) & $-11.86^{* * *}$ & $-11.26^{* * *}$ & 0.10 & - & - & - \\
\hline I Interest rate & $-3.25^{*}$ & -2.35 & $0.21^{* *}$ & $-5.04^{* * *}$ & $-26.67 * * *$ \\
\hline I Industrial production & -3.05 & $-11.46^{* * *}$ & 0.11 & $-4.72^{* * *}$ & $-46.51^{* * *}$ & 0.08 \\
\hline I Inflation rate & -2.85 & -2.38 & $0.15^{* *}$ & $-3.56^{* * *}$ & $-24.80^{* * *}$ & 0.05 \\
\hline
\end{tabular}

Note: 1 indicates that the variable is employed in logarithmic form. ADF: Augmented Dickey-Fuller Test (null hypothesis: unit root), PP: Phillips-Perron Test (null hypothesis: unit root), KPSS: Kwiatkowski-PhillipsSchmidt-Shin Test (null hypothesis: stationarity). *, ** and *** show rejection of null hypothesis at the $10 \%-$, 5\%-, and 1\%-level, respectively. Unit root tests include linear time trend. Lag length according to Schwarz Information Criterion. 393 obs.

Table 3 Unit root tests post-unification sample (10/1990-01/2008)

\begin{tabular}{|l|l|l|l|l|l|l|}
\hline & Levels & \multicolumn{2}{l|}{$\mathbf{1}^{\text {st }}$ Differences } \\
\hline & ADF & PP & KPSS & \multicolumn{2}{l|}{ ADF } & \multicolumn{1}{l|}{ PP } \\
\hline I Unemployment & $-4.63^{* * *}$ & $-4.84^{* * *}$ & $0.28^{* * *}$ & $4.48^{* * *}$ & $-11.17^{* * *}$ & $0.13^{*}$ \\
\hline I Oil price (oil) & $-3.75^{* *}$ & $-3.16^{*}$ & $0.24^{* * *}$ & $-12.54^{* * *}$ & $-10.08^{* * *}$ & 0.05 \\
\hline I Oil price increase (dloilpos) & $-11.26^{* * *}$ & $-11.31^{* * *}$ & 0.10 & - & - & - \\
\hline I Net oil price increase (nopi) & $-13.21^{* * *}$ & $-26.56^{* * *}$ & $0.13^{*}$ & - & - & - \\
\hline I Interest rate & -2.02 & -0.98 & $0.22^{* * *}$ & $-3.92^{* *}$ & $-11.72^{* * *}$ & 0.08 \\
\hline I Industrial production & -2.63 & $-8.81^{* * *}$ & $0.29^{* * *}$ & -2.89 & $-50.26^{* * *}$ & $0.18^{* *}$ \\
\hline I Inflation rate & -2.05 & -1.71 & $0.34^{* * *}$ & $-3.56^{* *}$ & $-15.14^{* * *}$ & 0.05
\end{tabular}

Note: 1 indicates that the variable is employed in logarithmic form. ADF: Augmented Dickey-Fuller Test (null hypothesis: unit root), PP: Phillips-Perron Test (null hypothesis: unit root), KPSS: Kwiatkowski-PhillipsSchmidt-Shin Test (null hypothesis: stationarity). *, ** and *** show rejection of null hypothesis at the $10 \%-$, $5 \%-$, and 1\%-level, respectively. Unit root tests include linear time trend. Lag length according to Schwarz Information Criterion. 208 obs. 


\section{References}

Barsky, R.B. and L. Kilian (2004), Oil and the macroeconomy since the 1970s, Journal of Economic Perspectives 18, 115-134.

Brown, S.P.A. and M.K. Yücel (1999), Oil prices and the economy, Southwest Economy 4, 16.

Brown, S.P.A. and M.K. Yücel (2002), Energy prices and aggregate economic activity: An interpretative study, Quarterly Review of Economics and Finance 42, 193-208.

Farzanegan, M.R. and G. Markwardt (2008), The effects of oil price shocks on the Iranian economy, Faculty of Business Management and Economy, Dresden University of Technology.

Ferderer, J.P. (1996), Oil price volatility and the macroeconomy, Journal of Macroeconomics $18,1-26$.

Flaig, G. (2005), Time series properties of the German production index, Allgemeines Statistisches Archiv 89, 419-434.

Franz, W. (1983), The past decade's natural rate and the dynamics of German unemployment. A case against demand policy? European Economic Review 21, 51-76.

German Council of Economic Experts (2006), Conflicting interests - missed opportunities, Report 2006/2007, Wiesbaden.

Granger, C. W. J. and P. Newbold (1974), Spurious regressions in econometrics, Journal of Econometrics 2, 111-120.

Greening, L.A., W.B. Davis, L. Schipper, and M. Khrushch (1997), Comparison of six decomposition methods: Application to aggregate energy intensity for manufacturing in 10 OECD countries, Energy Economics 19, 375-390.

Hamilton, J.D. (1996), This is what happened to the oil price-macroeconomy relationship, Journal of Monetary Economics 38, 215-220.

Hamilton, J.D. (1983), Oil and the macroeconomy since World War II, Journal of Political Economy 91, 228-248.

He, Z. and K. Maekawa (2001), On spurious Granger causality, Economics Letters 73, 307313.

Hooker, M.A. (1996), What happened to the oil price-macroeconomy relationship? Journal of Monetary Economics 38, 195-213.

IEA - International Energy Agency (2008), World Energy Outlook 2008, Paris.

Jones, D.W., P.N. Leiby, and I.K. Paik (2004), Oil price shocks and the macroeconomy: What has been learned since 1996, The Energy Journal 25, 1-32. 
Koop, G., M.H. Pesaran, and S.M. Potter (1996), Impulse response analysis in nonlinear multivariate models, Journal of Econometrics 74, 119-147.

Lin, S.X. (2008), Effect of Chinese oil consumption on world oil prices, Cass Business School, City University London.

Meyer, M. and P. Winker (2005), Using HP filtered data for econometric analysis: Some evidence from Monte Carlo simulations, Allgemeines Statistisches Archiv 89, 301-318.

Mork, K.A. (1989), Oil and the Macroeconomy When Prices Go Up and Down: An Extension of Hamilton’s Results, Journal of Political Economy 97, 740-744.

Naka, A. and D. Tufte (1997), Examining impulse response functions in cointegrated systems, Applied Economics 29, 1593-1603.

Papapetrou, E. (2001), Oil price shocks, stock market, economic activity and employment in Greece, Energy Economics 23, 511-532.

Rotemberg, J.J. and M. Woodford (1996), Imperfect competition and the effects of energy price increases on economic activity, Journal of Money, Credit and Banking 28, 549-577.

Schmidt, T. and T. Zimmermann (2005), Effects of oil price shocks on German business cycles, RWI: Discussion Papers No. 31, Essen.

Schmidt, T. and T. Zimmermann (2007), Why are the effects of recent oil price shocks so small? Ruhr Economic Paper No. 21, Essen.

Sims, C.A. (1980), Macroeconomics and Reality, Econometrica 48, 1-48.

Steiner, V. (2001), Unemployment Persistence in the West German Labour Market: Negative Duration Dependence or Sorting? Oxford Bulletin of Economics \& Statistics 63, 91-113.

Tanaka, N. (2008), Energy security, sustainability and dialogue, Presentation at the International Energy Forum Secretariat, Riyadh.

ZEW - Centre for European Economic Research (2008), Energie wird teurer, Schwerpunkt Energiemarkt 2/2008, p. 3-4. 